\title{
PENDAMPINGAN KETERAMPILAN PENGGUNAAN SISTEM INFORMASI AKUNTANSI PROGRAM SPREADSHEET UNTUK KELAS X AKUNTANSI DAN MIND YOUR OWN BUSINESS (MYOB) UNTUK KELAS XI AKUNTANSI DI SMKN 1 BANYUSARI SECARA DARING
}

\author{
Yanti ${ }^{1}$, Muhamad Najmul Munir ${ }^{2}$ \\ Universitas Buana Perjuangan Karawang \\ Program Studi Akuntansi, Fakultas Ekonomi dan Bisnis \\ Universitas Buana Perjuangan Karawang \\ yanti@ubpkarawang.ac.id ${ }^{1}$ ak18.muhamadmunir@mhsubp.ac.id ${ }^{2}$ \\ Abstrak
}

Pengabdian ini dilaksanakan di SMK Negeri 1 Banyusari, tujuan dari pengabdian ini adalah untuk membentuk keterampilan guru dan siswa dalam mengaplikasikan pengolahan bilangan pada kelas X mata pelajaran Akuntansi dan komputer akuntansi selama pembelajaran online dan sebagai media pelaksanaan pembelajaran online bagi guru yang tidak dapat berinteraksi langsung dengan siswa karena kendala jaringan internet yang tidak stabil. Metode yang dipakai dalam pengabdian ini adalah dengan daring mengingat kondisi yang masih pandemic, pengabdian ini diharapkan menjadi solusi dari permasalahan yaitu untuk meningkatkan kreativitas guru khususnya dalam bidang akuntansi serta untuk meningkatkan agar pembelajaran online berjalan lebih baik dengan menggunakan media pembelajaran yang lebih menarik seperti video animasi, tayangan slide power point atau bisa juga dengan tatap muka. belajar tatap muka seminggu sekali dengan memperhatikan protokoler kesehatan.

\section{Kata kunci: aplikasi akuntansi,myob,spreedsheet}

\begin{abstract}
This service is carried out at SMK Negeri 1 Banyusari, the purpose of this service is to form student skills in applying number processing in class $X$ accounting subjects and accounting computers during online learning and as a medium for implementing online learning for teachers who cannot interact directly with students because unstable internet network constraints. The method used in this service is online considering the conditions are still a pandemic, this service is expected to be a solution to the problem, namely to increase teacher creativity, especially in the accounting field and to improve online learning so that online learning runs better by using more interesting learning media such as animated videos., power point slide show or it could be face to face. face-to-face learning once a week with due observance of health protocols.
\end{abstract}

Keywords: accounting application, myob, spreadsheet 


\section{PENDAHULUAN}

Secara umum dalam pendidikan tidak hanya mata pelajaran teori tetapi ada mata pelajaran yang mengutamakan praktik. Pada Sekolah Menengah Kejuruan (SMK), peserta didik tidak hanya belajar teori tetapi peserta didik juga diajarkan praktik. Mata pelajaran yang mengutamakan praktik diantaranya mata pelajaran aplikasi pengolahan angka dan komputer akuntansi menggunakan sistem informasiakuntansi program Spreadsheet dan Mind Your Own Business (MYOB).

Berdasarkan observasi awal di SMKN 1 Banyusari kami mendapatkan informasi bahwa program Spreadsheet merupakan materi yang ada di dalam mata pelajaran aplikasi pengolahan angka untuk kelas X Akuntansi sedangkan program Mind Your Own Business (MYOB) merupakan materi yang ada di dalam mata pelajaran komputer akuntansi untuk kelas XI Akuntansi. Namun sejak kasus pandemic Corona Virus Disease (covid-19) mulai meningkat di Indonesia, Kementerian Pendidikan dan Kebudayaan (Kemendikbud) mengeluarkan surat edaran Nomor 3 Tahun 2020 tentang pencegahan Corona Virus Disease (covid-19) pada satuan Pendidikan sehingga proses pembelajaran dilakukan dengan metode daring (dalam jaringan).

Dengan kondisi sekarang pembelajaran praktikum dilakukan secara daring menggunakan Google Classroom dan aplikasi whatsapp yang berpotensi menimbulkan beberapa kesulitankesulitan yang dihadapi seluruh peserta didik diantaranya kurang memahami penjelasan dari guru terkait program-program dalam sistem informasi akuntansi dan kurang termotivasi untuk berlatih secara mandiri yang bisa menyebabkan rendahnya keterampilan menggunakan program- program dari sistem informasi akuntansi. Karena adanya kendala seperti itu maka penulis tertarik melakukan Pengabdian walaupun secara dengan daring tema keterampilan menggunakan sistem informasi akuntansi program Spreadsheet untuk kelas X Akuntansi dan Mind Your Own Business (MYOB) untuk kelas XI Akuntansi di SMKN 1 Banyusari.

\section{METODE}

Media yang digunakan dalam pengabdian ini adalah software Myob dan spreadsheet, pengabdian ini dilaksanakan seacra daring di SMK Negeri I Banyusari. Tahap awal yang dilakukan adalah menginstal software ini ke masing -msing laptop peserta serta memberikan sedikit pemaparan kepada para siswa dan guru untuk mengoperasikan software Myob dan 
Spreadsheet terutama bagi guru yang sudah usia lanjut. Selain itu pada tahap awal juga dijelaskan tentang penggunaan software ini serta kaitannya dengan beberapa materi akuntansi di tingkat Sekolah Menengah Kejuruan (SMK) serta memberi sedikit selingan terhadap metode-metode pembelajaran,diskusi dan Tanya jawab, Tahap selanjutnya adalah tim melakukan pendampingan secara daring terhadap guru-guru tersebut dimana tim berperan sebagai tutor di depan dan beberapa tim lainnya memandu secara daring dari tempat peserta. Tahap tersebut membutuhkan waktu yang cukup lama karna peserta dituntut harus mampu menjelaskan materi di kelas masing-masing dengan menggunakan software Myob dan Spreadsheet. Tentu saja percobaan yang dilakukan bukan Cuma sekali, bahkan berkali-kali dilakukan terhadap sebuah topik agar guru yang bersangkutan mahir dan tidak lupa. Setelah peserta mahir, tim memberikan soal-soal berkaitan dengan akuntansi yang harus dikerjakan dengan bantuan software tersebut sebagai umpan balik sekaligus menjawab keberhasilan indicator yang telah ditentukan oleh tim di hari selanjutnya

\section{HASIL DAN PEMBAHASAN}

Pada bagian ini hasil dan pembahasan dari hasil pengabdian kepada masyarakat yang diperoleh disajikan dalam bentuk uraian, baik secara kualitatif maupun kuantitatif secara jelas, tepat, dan lengkap yang dapat menggunakan informasi dalam bentuk gambar/grafik/tabel/uraian secara aktual. Dan Pembahasan berisi ringkasan hasil pengabdiannya, keterkaitan dengan konsep atau teori dan hasil pengabdian lain yang relevan, interpretasi temuan, keterbatasan pengabdian, serta implikasinya terhadap perkembangan konsep atau keilmuan.

Pengabdian ini dilakukan dengan menggunakan metode ceramah seacra daring yang kemudian dilakukan Tanya jawab secara terbuka antara guru serta siswa X dan XI yang ada di SMKN 1 banyusari,,adapun pelaksanaannya dilakukan pada bulan Februari 2021 setelah dilakukan survei serta analisis yang dibutuhkan oleh mitra pengabdian, adapun metode yang dilakukan dalam pengabdian ini adalah dengan ceramah dan diskusi secara daring dengan beberapa tema yang dibutuhkan oleh mitra yakni pembelajaran dengan menggunakan media software myob dan spreadsheet dengan langsung praktek secara daring kelas X dan XI di SMKN I banyusari, dari hasil pengabdian ini dapat berdampak positif bagi para guru dan siswa kelas X dan XI yang ada SMKN I Banyusari untuk mendapatkan ilmu yang baru tentang pembelajaran dengan menggunakan media software akuntansi yaitu myob dan spreadsheet. 


\section{KESIMPULAN DAN SARAN}

Keterampilan merupakan kemampuan dasar pada diri manusia yang harus dilatih, diasah, serta dikembangkan secara terus menerus sehingga menjadi potensial dalam melakukan sesuatu. Keterampilan bisa mengalami perkembangan atau peningatan dengan proses belajar. Meskipun sekarang proses belajar dilakukansecara daring, pembelajaran secara daring di SMKN 1 Banyusari, khususnya mata pelajaran aplikasi pengolahan angka di kelas $\mathrm{X}$ Akuntansi dan mata pelajaran komputer akuntansi di kelas XI Akuntansi sudah baik dan sesuai dengan rencana pembelajaran siswa yang sudah ditetapkan.

Berdasarkan data yang sudah diuraikan bahwa pembelajaran daring ini masih memiliki kendala, salah satunya dalam pengumpulan tugas yang melewati batas waktu yang sudah ditentukan, disebabkan keterbatasan sinyal dan keterbatasan kouta dan urain dari bab-bab sebelumnya menjelaskan bahwa proses belajar daringmasih memiliki kendala yang berakibat bisa menurunya keterampilan peserta didik.Salah satunya, kurang berlatih mengerjakan soalsoal yang berkaitan dengan materiyang diberikan. Serta kurang menyadari bahwa sistem informasi akuntansi pentingdalam dunia kerja apalagi dalam ruang lingkup akuntansi.

Berdasarkan kelemahan yang ditemukan dalam proses belajar daring mata pelajaran aplikasi pengolahan angka di kelas X Akuntansi dan mata pelajaran komputer akuntansi di kelas XI Akuntansi, maka penulis mencoba memberikan sedikit saran yang mungkin bermanfaat dalam proses belajar daring di SMKN 1 Banyusari. Saran penulis adalah sebaiknya guru mata pelajaran memberikan latihan soal meliputi langkah-langkah, prosedur dan pengertian. Sehingga hal-hal tersebutbisa memicu dan meningkatkan keterampilan para siswa/i dalam menggunakan sistem infornasi akuntansi, khususnya spreadsheet dan mind your own bussines lalulebih sering memotivasi para peserta didik agar lebih percaya diri atau tidak malu untuk bertanya. 


\section{DAFTAR PUSTAKA}

Budiyono, A. \&. (2014). Pengantar Manajemen. Yogyakarta: Graha Ilmu.

Irwadi.

(2015). $\quad$ http://eprints.polsri.ac.id/.

Retrieved from http://eprints.polsri.ac.id/4960/3/BAB\%20II.pdf.

Musyafa. (2014). Dari Masa Ke Masa Aplikasi Pengolah Angka. www.academia.education.

Musyafa, A. I. (2014). Dari Masa Ke Masa Aplikasi Pengolah Angka. wwwacademia education.

Pusdiklat. (2020, Maret 24). pusdiklat.kemdikbud.go.id. Diambil kembali darisurat-edaranmendikbud-no-4-tahun-2020-tentang-pelaksanaan-kebijakan- pendidikan-dalammasa-darurat-penyebaran-corona-virus-disease-covid-1-9/:

https://pusdiklat.kemdikbud.go.id/surat-edaran-mendikbud-no-4-tahun-2020tentang-pelaksanaan-kebijakan-pendidikan-dalam-masa-darurat- penyebaran-coronavirus-disease-covid-1-9/

Susanto, A. (2013 : 8). Sistem Informasi Akuntansi. Bandung: Lingga Jaya.

Susanto, A. (2017 : 207). Sistem Informasi Akuntansi Pemahaman Konsep SecaraTerpadu, Edisi Perdana. Bandung: Lingga Jaya.

Susanto, A. (2017 : 80). Sistem Informasi Akuntansi - Pemahaman Konsep Secara Terpadu,Edisi Perdana. Bandung: Lingga Jaya.

Zaenuri, M. (2013). Penerapan Aplikasi Software MYOB pada PerusahaanDagang. Jakarta: INFOKAM. 